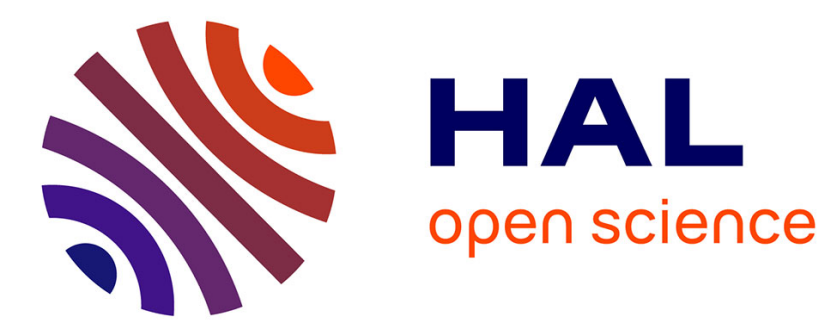

\title{
Long distance foraging and recruitment by a stingless bee, Melipona mandacaia
}

Brunno Kuhn-Neto, Felipe A.L. Contrera, Marina S. Castro, James C. Nieh

\section{To cite this version:}

Brunno Kuhn-Neto, Felipe A.L. Contrera, Marina S. Castro, James C. Nieh. Long distance foraging and recruitment by a stingless bee, Melipona mandacaia. Apidologie, 2009, 40 (4), 10.1051/apido/2009007 . hal-00892028

\section{HAL Id: hal-00892028 https://hal.science/hal-00892028}

Submitted on 1 Jan 2009

HAL is a multi-disciplinary open access archive for the deposit and dissemination of scientific research documents, whether they are published or not. The documents may come from teaching and research institutions in France or abroad, or from public or private research centers.
L'archive ouverte pluridisciplinaire HAL, est destinée au dépôt et à la diffusion de documents scientifiques de niveau recherche, publiés ou non, émanant des établissements d'enseignement et de recherche français ou étrangers, des laboratoires publics ou privés. 


\title{
Long distance foraging and recruitment by a stingless bee, Melipona mandacaia*
}

\author{
Brunno KuHN-Neto ${ }^{1}$, Felipe A.L. CONTRERA ${ }^{2,3}$, Marina S. CASTRO ${ }^{1,4}$, \\ James C. NIEH ${ }^{2}$ \\ ${ }^{1}$ Universidade Estadual de Feira de Santana, Departamento de Ciências Biológicas, Feira de Santana, Bahia, \\ Brazil \\ ${ }^{2}$ University of California San Diego, Division of Biological Sciences, Section of Ecology, Behavior, \\ and Evolution, La Jolla, California, USA \\ ${ }^{3}$ Current address: Universidade Federal do Pará, Instituto de Ciências Biológicas, Belém, PA, Brazil \\ ${ }^{4}$ Empresa Baiana de Desenvolvimento Agrícola, Laboratório de Abelhas, Salvador, Bahia, Brazil
}

Received 24 October 2008 - Revised 13 December 2008 - Accepted 16 December 2008

\begin{abstract}
Body size is hypothesized to play a major role in animal foraging, particularly in pollinators. In general, species with larger bodies forage over greater distances. Studies have found support for this body size-foraging range hypothesis across a wide variety of pollinator species, but have not investigated the possibility that this effect also applies within a pollinator species. We trained foragers of the stingless bee Melipona mandacaia to feeders in their native habitat under natural conditions, and found that larger foragers forage at and recruit to significantly greater distances than smaller foragers. The maximum foraging and recruitment distances are significantly greater (by $24 \%$ and $48 \%$ respectively) for larger as compared to smaller foragers. We also provide the first direct evidence that stingless bees can forage in their native habitat at distances up to $2.1 \mathrm{~km}$ and recruit over $1 \mathrm{~km}$ from their nest, recruiting more than $230 \%$ farther than previously reported for any stingless bee feeder experiments. Natural size variation among colonies within the same species may play a role in foraging range, and could thus influence plant gene flow and population structure.
\end{abstract}

stingless bees / foraging range / body size / recruitment / size variation

\section{INTRODUCTION}

Bees are among the most important insect pollinators in a wide variety of ecosystems (Bawa, 1990), especially in neotropical lowland rain forests (Bawa et al., 1985). Many bee species are long distance foragers that can, depending upon seasonal food densities, forage over several kilometers (Dornhaus et al., 2006), and thus influence plant gene flow (Bawa et al., 1985). Researchers have therefore examined predictors of foraging ranges in different bee species, principally

Corresponding author: J.C. Nieh, jnieh@ucsd.edu

* Manuscript editor: Stan Schneider the strong effect of body size (Araujo et al., 2004; Greenleaf et al., 2007; Pereboom and Biesmeijer, 2003; van Nieuwstadt and Iraheta, 1996). For example, Araujo et al. (2004) concluded that $75 \%$ of maximum stingless bees flight distances could be attributed to worker body size. However, the foraging ranges of most bee species are unknown (Greenleaf et al., 2007).

Relatively few studies have directly measured foraging distances (quantifying how far individuals travel to forage on natural food sources), despite the importance of this data for parameterizing ecological models, determining adequate sizes for refugia supporting these keystone pollinators, and understanding the evolution of bee foraging 
strategies. Foraging range can be measured indirectly through capture and release studies that model the probability of a released forager returning to the nest (Goulson and Stout, 2001; Roubik and Aluja, 1983). This probability should decrease when foragers are released in distant areas they are not familiar with.

Genetic analysis of bees captured at sites around the nest can yield direct estimates of foraging distance (Darvill et al., 2004). To date, no published studies have used genetic analysis to determine meliponine foraging ranges. Finally, bees can be trained to feeders, with the maximum foraging distance measured as the maximum training distance. Unlike capture and release or genetic analysis, training provides a direct measure of the maximum distances at which the recruitment communication is used. Feeder training studies can therefore provide key information about the recruitment communication systems that have evolved in response to different environments and to fill diverse ecological niches.

We focused on stingless bees (Hymenoptera, Apidae, Meliponini), the only native neotropical pollinators known to recruit nestmates to specific locations (Nieh, 2004). Stingless bees are significant pollinators throughout the tropics (Roubik et al., 1986), and exhibit a wide span of foraging distances. Kerr (1959) states that small bees such as Plebeia mosquito (3 to $4 \mathrm{~mm}$ in length) can be trained to a feeder up to $500 \mathrm{~m}$ away and recruit up to $300 \mathrm{~m}$ (Piracicaba, Brazil). Medium sized bees such as Trigona spinipes $(5 \mathrm{~mm})$ can be trained to feeders up to $840 \mathrm{~m}$ and recruit up to $630 \mathrm{~m}$ (Piracicaba, Brazil, Kerr, 1959). Large bees such as M. fuliginosa $(13-15 \mathrm{~mm})$ have a flight range of $2000 \mathrm{~m}$ (estimated from mark and recapure studies, Wille, 1975). Using a training feeder, Kerr (1959) found that $T$. trinidadensis can recruit nestmates via an odor trial to distances up to $800 \mathrm{~m}$ and could be trained to $980 \mathrm{~m}$ (even though training conditions were not optimal because the feeder was in a shaded area). To date, $980 \mathrm{~m}$ is the greatest published distance to which any stingless bee has been trained.

We therefore used feeder training to estimate maximum foraging distance and recruitment distance of the stingless bee, M. man- dacaia, in its native habitat. We chose this species because foragers can recruit nestmates to a specific distance and direction (Nieh et al., 2003a) and because this is one of relatively few meliponine species whose recruitment communication has been studied in detail. Foragers produce sounds inside the nest, and the temporal characteristics of these sounds are correlated with the quality of the food and its distance from the nest (Nieh et al., 2003b). Foragers can also deposit odors to assist orientation near the food source (Nieh et al., 2003c).

\section{MATERIALS AND METHODS}

\subsection{Colonies and study site}

Melipona mandacaia Smith is endemic to the Caatinga biome and occurs around the São Francisco and the Vaza Barris rivers in Brazil (Neves and Castro, 2006). This species ranges from the north of Minas Gerais, throughout the state of Bahia, and extends to the border of Pernambuco. It also occurs in Paraiba and Ceará (Silveira et al., 2002).

We conducted our studies in the Caatinga habitat (a semi-arid habit with deciduous plants) on a small farm in João Dourado, Bahia, Brazil $\left(41^{\circ} 41^{\prime} 15^{\prime \prime} \mathrm{W}\right.$, $\left.11^{\circ} 18^{\prime} 45^{\prime \prime} \mathrm{S}\right)$. The Caatinga habitat is a relatively arid and inhospitable ecosystem, with average annual temperatures of $28^{\circ} \mathrm{C}$, a prolonged dry season of food dearth and a short wet season of relative food abundance whose timing varies with region and year (Ab'Saber, 1974; Andrade-Lima, 1981; Rizzini, 1997). The flora is dominated by small deciduous trees and shrubs that frequently bear spines or thorns, cacti, and bromeliads (Andrade-Lima, 1981; Rizzini, 1997). In this habitat, M. mandacaia is an important native pollinator for many endemic species of flowering plants (Melo et al., 2002). We used three colonies during the dry season in 2005 from May to October (average annual rainfall is $55 \pm 48 \mathrm{~mm}$ per month and $13 \pm 14 \mathrm{~mm}$ from May to October, data from http://br.weather.com). A larger data set would have been preferable, but we were only able to obtain three colonies. This species is difficult to find and becoming increasingly rare. Individuals who find wild colonies frequently destroy them for their honey and do not keep them for meliponiculture. In addition, nest sites are rapidly disappearing because $M$. mandacaia prefers to nest in trees also valued for fence construction (Neves 
and Castro, 2006). Thus, opportunities to obtain and study M. mandacaia in its natural habitat are increasingly limited. All colonies had been at this location for several years. Colony flight activity corresponds strongly to the number of foragers per colony in M. bicolor (Hilário et al., 2000, 2003). Based upon their flight activity levels, all three $M$. mandacaia colonies were of similar size. Throughout all trials, natural food sources were limited principally to Mimosa tenuiflora (Mimosaceae) flowers.

Temperature can influence the time of day at which different meliponine species forage (Pereboom and Biesmeijer, 2003). However, we conducted all three trials within the same time period (0900-1700 h) at temperatures of 27-31 ${ }^{\circ} \mathrm{C}$. Melo et al. (2002) studied M. mandacaia foraging on natural food sources in the same Caatinga habitat around the São Francisco river in Bahia. They report that M. mandacaia and other Melipona species focus $70 \%$ of their forging activity at average temperatures ranging from 25 to $31^{\circ} \mathrm{C}$.

\subsection{Training and marking bees}

We trained bees to a grooved plate sucrose feeder $(10 \mathrm{~cm}$ diameter $)$ providing $60 \% \mathrm{v} / \mathrm{v}$ peppermint-scented sucrose solution $(9 \mu \mathrm{L}$ peppermint extract/L liter solution, McCormick and Co., Hunt Valley, Maryland, USA). Roubik and Buchmann (1984) demonstrated that $60 \%$ is the highest sugar concentration of natural nectar brought back to the colony by four Melipona species. We placed the feeder inside a yellow saucer on top of a $1 \mathrm{~m}$ high tripod. All bees landing on the feeder were individually and uniquely marked with acrylic paint on their thoraces. We recorded the number of (1) all foragers, (2) newcomers (foragers from the nest that had never previously visited any feeder) and (3) reactivated foragers (foragers that had fed from the feeder at a previous location, but not at the current or most recent position). Bees could freely visit, feed, and recruit for the feeder. At the end of each day, we verified that all feeder foragers came from the colony under study by checking for their return to the nest entrance (colony 1) or by examining bees inside the nest (colonies 2 and 3 ).

The trials with colonies 1,2 , and 3 respectively lasted $56 \mathrm{~h}$ over 7 days, $48 \mathrm{~h}$ over 6 days, and $32 \mathrm{~h}$ over 4 days. Trial duration was determined by the maximum distance to which the colony could be trained (see below). Rain halted foraging and prevented us from working for three days during the colony 2 trial, but did not affect trials with other colonies. We trained bees by placing the feeder in contact with the nest entrance, waiting until 10 bees fed, and then moving the feeder in $20 \mathrm{~m}$ steps. We moved the feeder $20 \mathrm{~m}$ further away when all bees visiting at the previous distance returned. If no bees from the previous distance returned, we moved the feeder $20 \mathrm{~m}$ back towards the nest. If the total number of foragers decreased by $50 \%$, we did not move the feeder for the rest of the day. The next morning, we placed the feeder at the final location from the previous day, remaining at this location until we reached the same number of foragers as on the previous day. If this did not occur within two hours, we moved to the next distance. This procedure allowed foragers a long period to find the feeder at its new position and provided a more conservative way of defining reactivated foragers. When foraging had reduced to only one bee visiting for two consecutive distances, we stopped the trial when no bee visited for one hour under normal weather conditions during peak visitation hours (1000-1600 h).

To measure forager body sizes, we collected 17 foragers from colony 1 and 20 foragers each from colonies 2 and 3 from the feeder at the end of trials with each colony. We measured forager head width (HW, distal eye edge to distal eye edge), interocular distance (ID, proximal eye edge to proximal eye edge), and intertegular distance (IT) with a micrometer and stereoscopic microscope (van Nieuwstadt and Iraheta, 1996; Greenleaf et al., 2007).

\subsection{Statistical analysis}

For each colony, we calculated the distance over which $75 \%, 95 \%$ and $100 \%$ of bees foraged to provide comparisons with other meliponine species (van Nieuwstadt and Iraheta, 1996). After residual analysis and normality testing, we transformed the data as follows: $X^{\prime}=(X+1)^{0.5}$ for the total number of foragers and $X^{\prime}=(X+3 / 8)^{0.5}$ for analyzing newcomers and reactivated foragers (because of zero values at some distances, Zar, 1984). We use JMP statistical software to perform ANOVA (alpha $=$ 0.05 , NS $=$ not significant) and mixed-model analysis (using Expected Mean Squares analysis to estimate the proportion of model variance explained by colony as a random effect). All foragers were individually marked, and thus we use the maximum distance reached by each forager to test the effect of forager size on maximum foraging distance. We 
Table I. Recruitment and foraging distances for M. mandacaia trial. For comparison with van Nieuwstadt and Iraheta (1996), we give distances over which 75\%, 95\%, and 100\% of total foraging activity occurred. Morphometric data show the average \pm SD of head width (HW), interocular distance (ID), and intertegular distance (IT). Body size measurements give the mean \pm 1 standard deviation of continuous, overlapping distributions.

\begin{tabular}{|c|c|c|c|c|c|c|}
\hline Colony & $\begin{array}{l}\text { Maximum } \\
\text { recruitment } \\
\text { distance } \\
\text { (m) }\end{array}$ & $\begin{array}{c}50 \% \\
\text { foraging } \\
\text { distance } \\
\text { (m) }\end{array}$ & $\begin{array}{c}75 \% \\
\text { foraging } \\
\text { distance } \\
(\mathrm{m})\end{array}$ & $\begin{array}{c}95 \% \\
\text { foraging } \\
\text { distance } \\
(\mathrm{m})\end{array}$ & $\begin{array}{c}100 \% \\
\text { foraging } \\
\text { distance } \\
\text { (m) }\end{array}$ & $\begin{array}{c}\text { Body size } \\
\text { measurements } \\
\text { HW } \\
\text { ID } \\
\text { IT }\end{array}$ \\
\hline $\begin{array}{l}1 \\
\text { (large } \\
\text { foragers) }\end{array}$ & 1220 & 1000 & 900 & 1640 & 2100 & $\begin{array}{l}3.8 \pm 0.1 \mathrm{~mm} \\
2.4 \pm 0.1 \mathrm{~mm} \\
2.9 \pm 0.1 \mathrm{~mm}\end{array}$ \\
\hline $\begin{array}{l}2 \\
\text { (small } \\
\text { foragers) }\end{array}$ & 620 & 500 & 900 & 1200 & 1840 & $\begin{array}{l}3.4 \pm 0.1 \mathrm{~mm} \\
2.3 \pm 0.1 \mathrm{~mm} \\
2.6 \pm 0.1 \mathrm{~mm}\end{array}$ \\
\hline $\begin{array}{l}3 \\
\text { (small } \\
\text { foragers) }\end{array}$ & 1020 & 600 & 880 & 1180 & 1560 & $\begin{array}{l}3.5 \pm 0.1 \mathrm{~mm} \\
2.3 \pm 0.1 \mathrm{~mm} \\
2.6 \pm 0.1 \mathrm{~mm}\end{array}$ \\
\hline
\end{tabular}

use post-hoc Tukey HSD tests to compare forager sizes among colonies. Morphometric measures are highly correlated and thus we applied the sequential Bonferroni correction as a conservative means of evaluating the significance of the body measurement results (Sokal and Rohlf, 1981).

\section{RESULTS}

\subsection{Forager sizes}

There is little intra-colonial variation in the size of foragers visiting our feeder (Tab. I). One standard deviation corresponds to $1.5-4.0 \%$ of the average $\mathrm{HW}, 2.0-2.9 \%$ of average ID, and $3.4-4.8 \%$ of IT within each colony. However, there is significant variation in the forager sizes between colonies (for all measured size parameters: $F_{2,54} \geqslant 38.6, P<$ 0.0001, Bonferroni critical alpha $=0.017$ ). The foragers fall into two significantly different size classes (Tab. I). For all measured parameters, foragers from colony 1 were significantly larger than foragers from colonies 2 and 3 (Tukey-HSD $Q=2.41, P<0.05$ ). There were no significant differences between forager sizes from colonies 2 and 3 (Tukey-HSD $Q=2.41, P>0.05)$. On average, the HW, ID, and IT of foragers from colony 1 are respectively $9 \%, 6 \%$, and $12 \%$ larger than those of colonies 2 and 3 . Thus, relative to the large foragers, the small foragers were respectively 5.6, 3.0 , and 2.8 standard deviations smaller in average HW, ID, and IT.

\subsection{Foraging distances}

Overall, M. mandacaia foragers achieved a maximum foraging distance of $2100 \mathrm{~m}$ and a maximum recruitment distance of $1220 \mathrm{~m}$. The maximum foraging distance was $2100 \mathrm{~m}$ for the colony with large foragers and $1560 \mathrm{~m}$ and $1840 \mathrm{~m}$ for the colonies (1 and 2) with small foragers (Fig. 1, Tab. I). Distance and forager size (categorized as small or large) strongly and significantly affect total forager number (Full model: $R^{2}=0.79$, $F_{3,277}=347.7, P<0.0001$; distance effect: $F_{1,277}=1016.5, P<0.0001$; size effect: $F_{1,277}=107.9, P<0.0001$; interaction NS).

We next examined the two components of total forager number (newcomers and reactivated foragers) separately within each size class. In the trial with large foragers, the number of newcomers $\left(F_{1,104}=35.1, P<\right.$ $\left.0.0001, R^{2}=0.25\right)$ is negatively correlated 

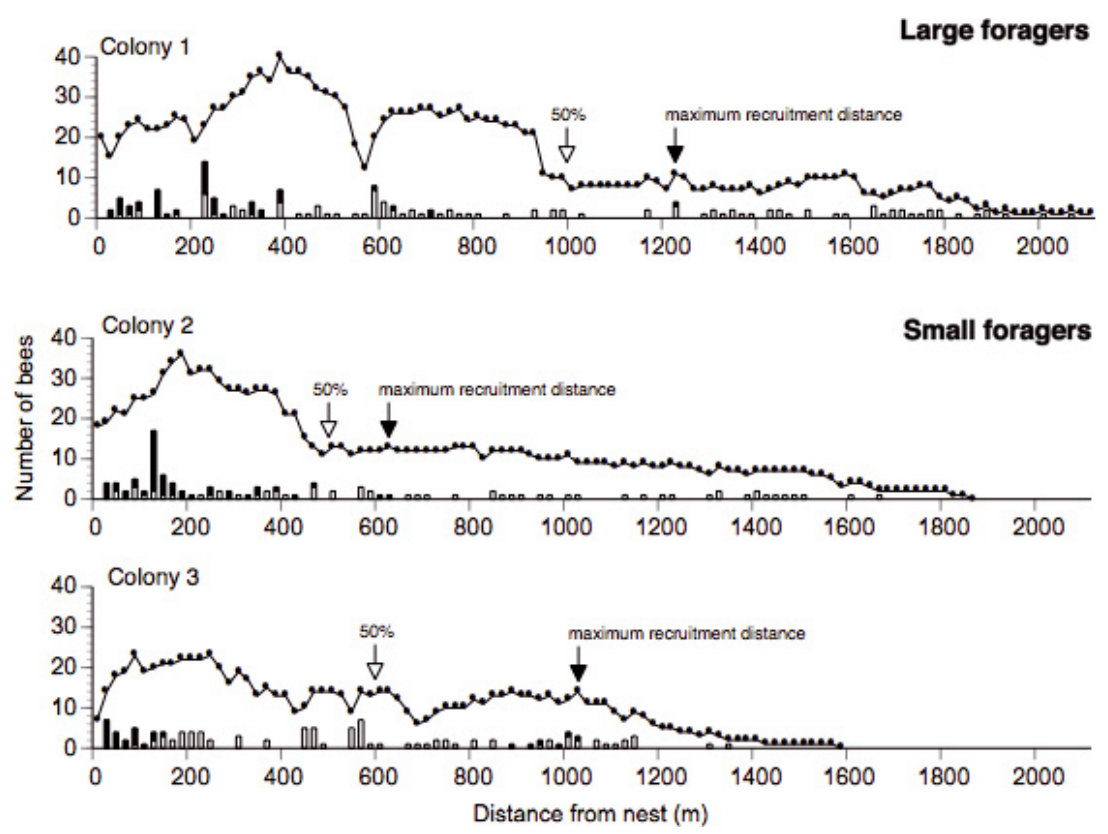

Figure 1. Distribution of total foragers (filled circles connected with line), recruits (filled rectangles), and reactivated foragers (open rectangles) in all trials. The median point of the distribution of total foragers $(50 \%)$ and the maximum recruitment distance (recruitment limit) are shown.

with distance. The number of reactivated foragers is not correlated with distance (Fig. 1b, $\left.F_{1,104}=2.2, P=0.14, R^{2}=0.02\right)$. Thus, the number of newcomers, but not reactivated foragers, steadily decreased with increasing distance for large foragers.

In trials with small foragers, the number of newcomers is negatively correlated with distance (overall model $F_{2,169}=29.1, P<$ $0.0001, R^{2}=0.26$; distance effect $F_{1,169}=$ 57.3, $P<0.0001$, colony effect NS). Likewise, the number of reactivated foragers is negatively correlated with distance (overall model $F_{2,169}=11.0, P<0.0001, R^{2}=0.12 ;$ distance effect $F_{1,169}=19.4, P<0.0001$, colony effect NS). Thus, in the colonies with small foragers, decreases in newcomers and reactivated foragers significantly contributed to the decline in foraging with increasing distance (Fig. 1).

\section{DISCUSSION}

These data provide the first demonstration that stingless bees foragers, under natural con- ditions in their native habitat, can be trained to and recruit for rich food sources over a kilometer from the nest. Melipona mandacaia workers foraged at distances up to $2.1 \mathrm{~km}$ and recruited to distances over $1 \mathrm{~km}$ away. Our results suggest that intraspecific forager size may also affect foraging range within a bee species. Colonies foraged at and recruited to significantly greater maximum distances when they contained larger foragers as compared to colonies with smaller foragers. The maximum average foraging distances for large and small foragers were $2100 \mathrm{~m}$ and $1700 \mathrm{~m}$ respectively. The maximum average recruitment distances for large and small foragers were $1220 \mathrm{~m}$ and $820 \mathrm{~m}$ respectively.

How do the foraging ranges of $M$. mandacaia, as measured in our study, compare with the maximum distances reported in bumble bees and honey bees? Bumble bees (Bombus terrestris) can forage up 1-5 km from their nest, as determined by observations of dyed bees on natural flowers and by analysis of pollen collected from foragers (Hertfordshire, UK, Osborne et al., 2008). Based upon a mark 
and recapture study, $B$. terrestris may be able to forage as far as $9.8 \mathrm{~km}$ (Goulson and Stout, 2001). Using molecular identification methods, Darvill et al. (2004) reported maximum foraging ranges of $312 \mathrm{~m}$ (B. pascuorum) and $625 \mathrm{~m}$ (B. terrestris). Different honey bee species can be trained to feeders $350-12500 \mathrm{~m}$ from the nest and will waggle dance to recruit nestmates for distances of 300-10000 m. In honey bees, the greatest foraging and recruitment distances have been reported for Apis mellifera in Europe and North America during food dearth (Dyer and Seeley, 1991). By inferring foraging distances from the waggle dance, Beekman and Ratnieks (2000) reported an average foraging distance of $5.5 \mathrm{~km}$ and a maximum of $14.5 \mathrm{~km}$ (in August, Sheffield, UK).

Among stingless bees, our measured foraging ranges are the largest that have been directly determined to date, exceeding by $214 \%$ the maximum distance previously reported for feeder training experiments $(980 \mathrm{~m}$ by $T$. trinidadensis, Kerr, 1959). Roubik and Aluja (1983) conducted studies in which they captured bees at the nest, marked them, and released them at various distances from the nest. They found that bees could still return to their nests after being released $2.1 \mathrm{~km}$ away for Melipona and $1.5 \mathrm{~km}$ away for Trigona species. Based upon regression analysis, they predicted maximum range distances of $2.4 \mathrm{~km}$ and $1.7 \mathrm{~km}$ respectively. Our data fall within the predicted maximum for Melipona.

As with all methods of foraging range estimation, feeder training has its limitations (Greenleaf et al., 2007). The maximum distances obtained through training are dependent upon the availability of natural food sources and provide an estimate of how far bees could go to visit a food source, not necessarily how far they actually forage to visit floral resources. However, M. mandacaia are native to a Caatinga habitat in which the low density of natural food sources during the prolonged dry season should favor an extended foraging range, as we found. In comparison, van Nieuwstadt and Iraheta (1996) worked in a region with a higher density of floral resources, the neotropical dry forest at the end of the dry season in Guanacaste, Costa Rica. Here, they were able to train four different species of stingless bees to shorter distances of 130-720 $\mathrm{m}$ and found that foragers could still return to their nests after being released 623-853 m away.

Our results suggest that forager size may influence maximum foraging and recruitment range. To rigorously determine the effect of intraspecific body size on foraging range, it is desirable to have more colonies and a wider range of worker size difference among these colonies. With M. mandacaia, this may prove difficult because the species is increasingly rare and endangered by habitat destruction. This is unfortunate given that the relatively extreme and seasonally xeric habitat of $M$. mandacaia facilitates the study of long distance foraging and may contribute to substantial inter-colonial worker size differences. Poor feeding conditions may lead to the production of smaller Melipona workers (Kerr et al., 1966). For example, in the stingless bee, $M$. quadrifasciata, average worker size varies with colony conditions such that weaker colonies experiencing less food intake contain smaller foragers than stronger colonies (Ramalho et al., 1998). Differences in food intake may have led to the inter-colonial size differences that we found in M. mandacaia. Detailed research into the proximate causes of worker size variation in stingless bees would be valuable.

With some exceptions, our results generally fall within the foraging ranges predicted from various bee size models. Van Nieuwstadt and Iraheta (1996) derive a relationship between forager size (head width, HW) which, when applied to our data, yield a predicted foraging range of $1200 \mathrm{~m}$ for the large M. mandacaia foragers and $1022 \mathrm{~m}$ for the small foragers (van Nieuwstadt and Iraheta, 1996). Our foraging ranges are larger, perhaps due to ecosystem differences. Greenleaf et al. (2007) examined a wide range of corbiculate bees, including honey bees, stingless bees, and bumble bees and also found a significant relationship between body size (intertegular span, IT) and foraging range. Fitting our body size results with their equations yields the following predictions for large and small M. mandacaia foragers respectively: typical homing distances of $1696 \mathrm{~m}$ and $1534 \mathrm{~m}$; maximum 
homing of $1720 \mathrm{~m}$ and $1563 \mathrm{~m}$; maximum recruitment to $954 \mathrm{~m}$ and $842 \mathrm{~m}$; and maximum feeder training to $1291 \mathrm{~m}$ and $1156 \mathrm{~m}$. The maximum training distances that we obtained for $M$. mandacaia exceed these predictions.

By measuring the body sizes of foragers that were trained to the farthest distances, rather than measuring the body sizes of all foragers, we focused on inter-colonial differences. Ramalho et al. (1998) captured M. quadrifasciata anthidioides foragers exiting the nest entrance and thus ensured a broader sampling of forager sizes. In their study, one standard deviation corresponded to $5.1-5.5 \%$ of average HW and $2.4-3.0 \%$ of IT. We focused a more limited subset of foragers and found slightly less variation in $M$. mandacaia (one standard deviation corresponded to $1.5-4.0 \%$ of average HW and 3.4-4.8\% of IT).

Intra-colonial worker size differences may also be important. Waddington et al. (1986) examined 11 meliponine species and reported that stingless bees with greater within-nest size variation have less complex recruitment systems (ranked from basal to more derived according to the system of Kerr, 1969). Such intra-colonial forager size polymorphism is widespread in social insects and can be quite pronounced in ants (Hölldobler and Wilson, 1990), and bumble bees (Heinrich, 1979), but its effects on stingless bee foraging have yet to be fully explored.

\section{ACKNOWLEDGEMENTS}

We would like to thank Mr. Antonio Souza, who allowed us to use his house, land, and bee colonies, and Felipe Oliveira Nunes and Marco Aurélio Pereira de Andrade, who provided invaluable assistance in the field. We would also like to thank the anonymous reviewers whose comments have significantly improved our manuscript. This research was supported by NSF Grant O316697, and by EBDA (Empresa Baiana de Desenvolvimento Agrícola).

Butinage à longue distance et recrutement chez une abeille sans aiguillon, Melipona mandacaia.

Apidae / distance de butinage / taille corporelle / comportement de recrutement / variation de la taille
Zusammenfassung - Sammelverhalten und Rekrutierung zu weit entfernten Futterquellen bei der Stachellosen Biene Melipona mandacaia. Bei vielen Tierarten geht man davon aus, dass die individuelle Körpergrösse eine wichtige Rolle spielt in der Frage, in welcher Entfernung Futterquellen noch ausgebeutet werden. Bei Bienen fliegen grössere Arten in der Regel weiter enfernte Futterquellen an als kleinere Arten. Die Körpergrösse sollte damit von Bedeutung sein sowohl für die Definition der ökologischen Nische von Bienenarten, sowie auch für den Genfluss bei Pflanzen, die von ihnen bestäubt werden. Der Frage, ob die intraspezifische Variation in der Körpergrösse einen Einfluss auf den Sammelradius von Koloniemitgliedern bei sozialen Arten hat, wurde jedoch noch nicht nachgegangen. Wir untersuchten dies an einer Stachellosen Bienen, Melipona mandacaia, die in Brasilien in trockenen Caatinga-Habitaten vorkommt, wo Nahrungsquellen jahreszeitlich stark beschränkt sein können. Angesichts dieser Beschränkung an Futterquellen gingen wir davon aus, dass diese Bienen weit entfernte Futterquellen anfliegen und zu diesen auch rekrutieren könnten. Diese Untersuchungen führten wir an drei Völkern während der Trockensaison in Bahia durch. Wir bestimmten die maximalen Sammeldistanzen und die Rekturierdistanzen für Bienen, die auf den Besuch einer künstlichen Futterquellen mit $60 \%$ v/v Sacharose trainiert worden waren. Dabei markierten wir individuell alle an der Futterquelle ankommenden Bienen, um bestimmen zu können zu welchem Volk sie zurückkehrten und wo sie dort rekrutiert worden waren. Am Ende der Versuche sammelten wir Sammlerinnen von den Völkern $a b$ und bestimmten ihre Körpergrösse (Kopfbreite, Distanz zwischen den Augen und Thoraxbreite); Unsere Ergebnisse sind ein erster Hinweis darauf, dass Stachellose Bienen in ihrem natürlichen Habitat bis zu 2,1 km weit entfernte Futterquellen anfliegen und bis $\mathrm{zu} 1 \mathrm{~km}$ vom Nest entfernt auch rekrutieren können. Diese Werte liegen um $230 \%$ über den Werten, die bisher mittels künstlicher Futterquellen für Stachellose Bienen ermittelt worden waren. Des weiteren konnten wir eine beachtliche und signifikante Variation in der Körpergrösse der Sammlerinnen feststellen. Die Sammel- und die Rekrutierdistanzen für grosse Arbeiterinnen waren signifikant um $24 \%$, bzw. $48 \%$ weiter als die kleiner Arbeiterinnen.

Diese Ergebnisse weisen darauf hin, dass innerartliche Unterschiede in der Körpergrösse auch bei einer sozialen Bienenart den Sammelradius beeinflussen können. Völker mit grösseren Arbeiterinnen sammelten und rekrutierten über signifikant weitere Entfernungen als Völker mit kleineren Sammlerinnen. Die maximale Sammeldistanz grosser Arbeiterinnen lag bei $2100 \mathrm{~m}$, während die kleiner Sammlerinnen $1700 \mathrm{~m}$ betrug. Das gleiche galt für die Rekrutierdistanzen, mit Werten von $1220 \mathrm{~m}$ für grosse und $820 \mathrm{~m}$ für kleine Sammlerinnen. Die natürliche Variation der Körpergrösse zwischen 
Völkern der gleichen Art könnte damit das Sammelverhalten und in diesem Zusammenhang auch den Genfluss und die Poplationsstruktur von Pflanzenarten beeinflussen. Ähnliche intrakoloniale Unterschiede in der Körpergrösse sind bereits für andere soziale Insekten bekannt, insbesondere für Ameisen und Hummeln. Für Stachellose Bienen verstehen wir jedoch noch nicht im vollen Umfang die Bedeutung dieser Grössenunterschiede.

\section{Stachellose Bienen / Sammelradius / Körper- grösse / Rekrutierung / Grössenvariation}

\section{REFERENCES}

Ab'Saber A.N. (1974) O domínio morfoclimático semi-árido das Caatingas brasileiras, Geomorfologia 43, 1-39.

Andrade-Lima D. (1981) The Cattingas dominium, Rev. Brasil. Bot. 4, 149-153.

Araujo E.D., Costa M., Chaud-Netto J., Fowle H.G. (2004) Body size and flight distance in stingless bees (Hymenoptera: Meliponini): Inference of flight range and possible ecological implications, Braz. J. Biol. 64, 563-568.

Bawa K.S. (1990) Plant-pollinator interactions in tropical rain forests, Annu. Rev. Ecol. Syst. 21, 399422.

Bawa K.S., Perry D.R., Bullock S.H., Coville R.E., Grayum M.H. (1985) Reproductive biological of tropical lowland rain forest trees. II. Pollination mechanisms, Am. J. Bot. 72, 346-356.

Beekman M., Ratnieks F.L.W. (2000) Long-range foraging by the honey-bee, Apis mellifera L., Funct. Ecol. 14, 490-496.

Darvill B., Knight M.E., Goulson D. (2004) Use of genetic markers to quantify bumblebee foraging range and nest density, Oikos 107, 471-478.

Dornhaus A., Klügl F., Oechslein C., Puppe F., Chittka L. (2006) Benefits of recruitment in honey bees: effects of ecology and colony size in an individualbased model, Behav. Ecol. 17, 336-344.

Dyer F.C., Seeley T.D. (1991) Dance dialects and foraging range in three Asian honey bee species, Behav. Ecol. Sociobiol. 28, 227-234.

Goulson D., Stout J.C. (2001) Homing ability of the bumblebee Bombus terrestris (Hymenoptera: Apidae), Apidologie 32, 105-111.

Greenleaf S.S., Williams N.M., Winfree R., Kremen C. (2007) Bee foraging ranges and their relationship to body size, Oecologia 153, 589-596.

Heinrich B. (1979) Bumblebee economics, Harvard University Press, Cambridge, Massachusetts.

Hilário S.D., Gimenes M., Imperatriz-Fonseca V.L. (2003) The influence of colony size in diel rhythms of flight activity of Melipona bicolor Lepeletier (Hymenoptera, Apidae, Meliponini), in: Melo G.A.R., Alves dos Santos I. (Eds.), Apoidea Neotropica: Homenagem aos 90 anos de Jesus Santiago Moure, Editora UNESC, Criciúma, pp. 191-197.

Hilário S.D., Imperatriz-Fonseca V.L., Kleinert A.d.M.P. (2000) Flight activity and colony strength in the stingless Melipona bicolor bicolor (Apidae, Meliponinae), Rev. Bras. Biol. 60, 299-306.

Hölldobler B., Wilson E.O. (1990) The ants, Belknap Press of Harvard University Press, Cambridge, Massachusetts.

Kerr W.E. (1959) Bionomy of meliponids VI, in: Symposium on food gathering behavior of Hymenoptera, Ithaca, NY, USA, pp. 24-31.

Kerr W.E. (1969) Some aspects of the evolution of social bees, Evol. Biol. 3, 119-175.

Kerr W.E., Stort A.C., Montenegro M.J. (1966) Importância de alguns fatores ambientais na determinação das castas do gênero Melipona, Anais Acad. Brasil. Ciênc. 38, 149-168.

Melo A.M.C., Viana B.F., Neves E.L. (2002) Análise do padrão de uso de recursos florais por duas espécies de Melipona Illiger, 1806 (Hymenoptera: Apidae) nas dunas interiores do médio Rio São Francisco, Bahia, Brasil, Sitientibus série Ciênc. Biol. 2, 17-22.

Neves E.L., Castro M.S. (2006) Mandaçaia: uma abelha-chave para a conservação da caatinga, Candombá - Rev. Virtual 2, 1-3.

Nieh J.C. (2004) Recruitment communication in stingless bees (Hymenoptera, Apidae, Meliponini), Apidologie 35, 159-182.

Nieh J.C., Contrera F.A.L., Ramírez S., Imperatriz-Fonseca V.L. (2003a) Variation in the ability to communicate three-dimensional resource location by stingless bees from different habitats, Anim. Behav. 66, 1129-1139.

Nieh J.C., Contrera F.A.L., Rangel J., Imperatriz-Fonseca V.L. (2003b) Effect of food location and quality on recruitment sounds and success in two stingless bees, Melipona mandacaia and Melipona bicolor, Behav. Ecol. Sociobiol. 55, 87-94.

Nieh J.C., Ramírez S., Nogueira-Neto P. (2003c) Multi-source odor-marking of food by a stingless bee, Melipona mandacaia, Behav. Ecol. Sociobiol. 54, 578-586.

Osborne J.L., Martin A.P., Carreck N.L., Swain J.L., Knight M.E., Goulson D., Hale R.J., Sanderson R.A. (2008) Bumblebee flight distances in relation to the forage landscape, J. Anim. Ecol. 77, 406415.

Pereboom J.J.M., Biesmeijer J.C. (2003) Thermal constraints for stingless bee foragers: The importance of body size and coloration, Oecologia 137, 4250 . 
Ramalho M., Imperatriz F.V.L., Giannini T.C. (1998) Within-colony size variation of foragers and pollen load capacity in the stingless bee Melipona quadrifasciata anthidioides Lepeletier (Apidae, Hymenoptera), Apidologie 29, 221-228.

Rizzini C.T. (1997) Tratado de fitogeografia do Brasil, 2nd ed., Âmbito Cultural, Rio de Janeiro.

Roubik D.W., Aluja M. (1983) Flight ranges of Melipona and Trigona in tropical forest, J. Kans. Entomol. Soc. 56, 217-222.

Roubik D.W., Buchmann S.L. (1984) Nectar selection by Melipona and Apis mellifera (Hymenoptera: Apidae) and the ecology of nectar intake by bee colonies in a tropical forest, Oecologia 61, 1-10.

Roubik D.W., Moreno J.E., Vergara C., Wittmann D. (1986) Sporadic food competition with the African honey bee: projected impact on neotropical social bees, J. Trop. Ecol. 2, 97-111.
Silveira F.A., Melo G.A.R., Almeida E.A.B. (2002) Abelhas brasileiras, Sistemática e Identificação, Fundação Araucária.

Sokal R.R., Rohlf F.J. (1981) Biometry, 2nd ed., W. H. Freeman and Company, New York.

van Nieuwstadt M.G.L., Iraheta C.E.R. (1996) Relation between size and foraging range in stingless bees (Apidae, Meliponinae), Apidologie 27, 219-228.

Waddington K.D., Herbst L.H., Roubik D.W. (1986) Relationship between recruitment systems of stingless bees and within-nest worker size variation, J. Kans. Entomol. Soc. 59, 95-102.

Wille A. (1975) Las abjeas jicotes del género Melipona (Apidae, Meliponini), Rev. Biol. Trop. 24, 123 147.

Zar J.H. (1984) Biostatistical Analysis, 2nd ed., Prentice-Hall, Englewood Cliffs N.J. 